\title{
The Influence of Social Capital on Expatriates' Adjustment: The Moderating Effects of Work-Role Demand and Work-Family Conflict
}

\author{
Lee, Li-Yueh ${ }^{1 *}$; Nguyen, Phuoc-Thien ${ }^{2} ;$ Vu, Minh-Quan ${ }^{3}$ \\ ${ }^{1}$ Associate Professor, Department of Business Administration, Kun Shan University, No.195, Kunda Rd., Yongkang Dist., \\ Tainan City 710, Taiwan \\ ${ }^{2}$ Department of Business Administration, Nanhua University, No.55, Nanhua Road, Dalin Township, Chiayi County, \\ Taiwan \\ ${ }^{3}$ International School, Vietnam National University, Ha Noi, Vietnam \\ *Corresponding author. E-mail: wuleliyu@gmail.com
}

\begin{abstract}
Research related to the predictors of expatriate's adjustment and performance has been conducted extensively, nevertheless, expatriation remains a challenging job. Previous studies illustrated that approximately from $30 \%$ to $50 \%$ of expatriates are ineffective, or in other word, they are marginally effective. Among others, the issue of social capital, work-role demand, and work-family conflict are three of the most critical factors for the adjustment and performance of expatriation. This study also adopts the Takeuchi's stakeholder approach to identify the moderating role of work-role demand and work-family conflict that moderate the influence of social capital on cross-cultural adjustment. With a questionnaire survey approach, the data was obtained from 244 expatriates among Taiwanese multinational enterprises. The results of this study showed that (1) expatriate's social capital has a significant effect on the expatriates' cross-cultural adjustment; (2) work-role demand and work-family conflict serves as two moderating variables that will inhibit the influence of expatriates' social capital on cross-cultural adjustment. The results of this study are very beneficial to human resource manager in selecting, recruiting, evaluating, and managing their expatriates in the overseas marketplaces. These findings could also be very useful for academicians to develop further about theoretical foundation in expatriate management.
\end{abstract}

Keywords: Social capital, cross-cultural adjustment, work-role demand, work-family conflict

\section{INTRODUCTION}

\subsection{Research Background and Motivation}

Despite that many studies have concentrated on expatriation practices, the understanding of which influential factors for the expatriation effectiveness is still a large gap. Among others, the expatriate's social capital has regarded as a critical factor for expatriate's adjustment. Based on social exchange theory [1] [2] and social capital theory [3], latest studies have concerned that leader-member exchange (LMX) [4], perceived organizational support (POS) [5] are considered as some of the most influential determinants of social capital, which may further have significant influence on expatriate's adjustment and performance.

In addition to the above expatriate-centric approach, [6] stressed the family-related perspective as a serious consideration. For example, the influence of spouse, family adaption, and parent demand on expatriate's adjustment and performance are very critical and determined [4] [7] [8] [9] [10] [11]. In addition, according to other perspectives such as strain-based, time-based, and behavioral-based conflict, family-work conflict has a negative impact on expatriate's adjustment.

Furthermore, according to [12], work-role demand consists of role novelty, role ambiguity, role conflict, and role overload. Role novelty includes the differences between the past and the new roles. Black [13] argued that if the new position of the overseas assignment is significantly different from the previous positions, then the expatriate can have greater feeling of uncertainty and unpredictability regarding the results. This situation will become more deeper for the expatriate to justify whose behaviors are more eligible to the new situation. [12] also highlighted that, the transferred expatriate from one functional department to another, or to promote the expatriate to another job with greater responsibility will create more stressful condition that will hinder the adjustment and reduce the expatriate's performance.

According to [14], the factors of work-role demand may act as another moderating element inhibiting the influence of expatriate's social capital on cross-cultural adjustment. Therefore, even social capital can facilitate expatriate 
adjustment, work-role demand is critical that can inhibit the impacts of social capital on expatriate's adjustment and performance.

\subsection{Research Objectives}

This research has the objectives as follows:

(1) To identify the influence of expatriate's social capital and cross-cultural adjustment.

(2) To identify the moderating effects of work-family conflict and work-role demand for the influence of social capital on cross-cultural adjustment.

\section{DEFINITIONS OF RESEARCH CONSTRUCTS}

\subsection{Expatriate's Social Capital}

\subsubsection{Leader-Member Exchange (LMX)}

[15] stated that "LMX has been found to be related to an impressive set of important individual and organizational outcomes. [and] for the most part, LMX is positively associated with favorable attitudes such as job satisfaction and behaviors such as organizational citizenship".

Previous study has proven that LMX is positively connected to assistance and information [4] [16]. Moreover, affect, which can be examined by interpersonal, can be considered as not only a predictor but also an element of a high-quality exchange relationship [15] [17] [18] Affirmation is normally concerned about professional respect [15].

\subsubsection{Perceived Organizational Support}

Previous studies proved that individuals may obtain support from organizations, co-workers, supervisors, friends, and families. etc [19] [20]. In this study, the social support performance comes from the supervisor and organization. Organizational support theory [21] [22] stresses that individual employee develops global beliefs since the organization cares about their living and values their contributions [23].

[24] stressed the vital role that an organization plays in the expatriate's acculturation. Previous studies also stated that supervisor's support is an significant source of support for facing the stress at workplace [25] [26] and organizational support becomes an significant predictor of employees' adjustment that follows a transfer [27].

\subsection{Expatriate's Cross-Cultural Adjustment}

Expatriate adjustment is considered as the level of psychological comfort or discomfort with many aspects of the host culture, which was felt by an expatriate [28]. Previous studies have conceptualized the level of adjustment as a one-dimensional concept [29] [30]. However, contemporary research [13][30] [31] [32] [33] has suggested that the expatriate's cross-cultural adjustment is a multidimensional concept which includes: (1) work adjustment, which is considered as the expatriates' psychological comfort associated with assignments and duties abroad, and (2) interaction adjustment, which is the level of the expatriates' psychological comfort associated with the interaction with hosts both outside and inside the workplace.

\subsection{Work-Role Demand}

The predominant factor of work-role demand was found to have a negative and significant influence on the expatriates' adjustment. According to [12], role novelty includes the differences between the past and the new roles. Black and Stephen [13] argued that if the new position of the overseas assignment is significantly different from the past positions, then the expatriate can have greater feeling of uncertainty and unpredictability regarding the results. This situation will become more for the expatriate to justify which behaviors are more appropriate to the new situation. [12] also highlighted that the transfer of expatriate from one functional department to another, or to promote an expatriate to another job with greater responsibility, will create more stressful condition which will hinder the adjustment and reduce the expatriate's performance.

According to the role theory [41] and [42], role ambiguity (lack of clear information about the new role) will experience the anxiety, distorted reality, increased dissatisfaction, which will further result in less effectiveness. [14] argued that the higher the role ambiguity, the less will be for the employee to predict the outcomes of various behaviors and to use the past successful behavior to determine the new one. Therefore, role ambiguity may have a negative influence on the expatriate's effectiveness.

Role conflict refers to a set of roles that do not perfectly fit, which can cause higher distress, less satisfaction, and lower performance [43]. Black and Porter [44] argued that when the expatriates are experiencing role conflict, they will be less capable to decide which message should be ignored and when it should be followed, and thereby which execution and behavior should result in better performance. Therefore, role conflict will result in lower adaptation and lower expatriation's effectiveness.

Role overload refers to so many demands that are pointed to certain individual. According to [45], work overload may cause distress, which will further result in responding inadequately, and adjusting poorly. Therefore, role overload has a negative impact on the expatriate's adjustment and effectiveness.

\subsection{Work-Family Conflict}

In organizational behavior study, the work and family dimension has been an increasingly popular topic [35]. Previous studies have paid a special intention and stressed that work-to-family and family-to-work conflicts are different constructs [36]. 
There are several theoretical and practical causes for selecting the work-family conflict perspectives. First, this perspective obviously identifies the family members, [37] [38] that can not only impact but also be influenced by employees Second, while the stressor-stress-strain perspective has been implicitly implemented to the expatriate's adjustment issues [39] [40], it's still not in the scope of the expatriate's adjustment.

\subsection{Hypotheses}

Viewing about the independent, dependent, and moderating variables mentioned above, the following hypotheses were formulated in this study as follows:
$\mathrm{H}_{1}$ : Expatriate's social capital factors have positive influence on their cross-cultural adjustment.

$\mathrm{H}_{2}$ : Work-role demand will moderate the influence of expatriate's social capital on cross-cultural adjustment.

$\mathrm{H}_{3}$ : Work-family conflict will moderate the influence of expatriate's social capital on cross-cultural adjustment.

\section{METHODOLOGY}

\subsection{Research Framework}

The conceptual framework of this research is exhibited in Figure 1 as follow.

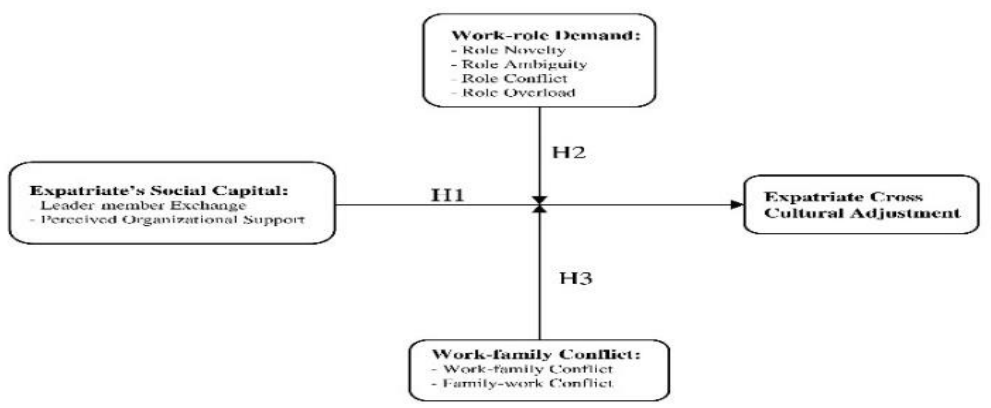

Figure 1 The conceptual framework of this study

\subsection{Participants and Sampling Plan}

On-line and off-line questionnaire surveys were used to acquire the opinions of sample from expatriates in Taiwan. Totally 600 returned questionnaires were distributed to foreign expatriates in the foreign multinational companies (MNCs) in Taiwan. Sampling frames of the respondents were obtained from (1) The U.S Firms, (2) The European Firms, and (3) The Japanese Firms, all are located in Taiwan. Those names of CEOs, presidents, vice presidents, and managers listed in each of the firms became the candidate respondents in this study. The online survey materials included a cover letter from researcher with universityaddressed. The expatriates were asked to state their responses about the questionnaire items related to all research constructs. Finally, 244 valid questionnaires were obtained.

\section{RESEARCH RESULTS AND DISCUSSIONS}

\subsection{Descriptive Analysis}

The descriptive analysis shows that the 244 valid respondents consist of 177 males $(72.54 \%)$ and 67 females $(27.46 \%)$, and most of the respondents' age were between 36 and 45 years old (42.2\%), followed by $26-35$ years old $(32.4 \%)$. Nearly $49.2 \%$ of the respondents had an education background with Master degree and followed by Bachelor degree $(43.0 \%)$. For annual income, most of the respondents claimed to earn 2.1 million to 3.0 million ( $36.1 \%)$, followed by the group claiming to earn 3.1 million to 4.0 million $(26.2 \%)$.

\subsection{Reliability and Validity Analysis}

Table 1 displays that the factor loadings of all items are greater than 0.6 (0.606 - 0.924), all item-to-total correlation coefficients are greater than 0.5 , and the Cronbach's alpha of all factors are also greater than 0.7 (0.814 - 0.939), which all exceed the generally accepted guideline from [46]. This concludes that the questionnaire items have high level of internal consistency and the factors are eligible to be used for data analysis further. 
Table 1 Factor Analysis and Reliability

\begin{tabular}{|c|l|c|c|c|c|c|}
\hline $\begin{array}{c}\text { Research } \\
\text { Construct }\end{array}$ & \multicolumn{1}{|c|}{ Factor } & $\begin{array}{c}\text { Factor } \\
\text { Loading }\end{array}$ & $\begin{array}{c}\text { Eigen- } \\
\text { Value }\end{array}$ & $\begin{array}{c}\text { Percentage of } \\
\text { Variance } \\
\text { Explained }\end{array}$ & $\begin{array}{c}\text { Item-to-Total } \\
\text { Correlation }\end{array}$ & $\begin{array}{c}\text { Cronbach's } \\
\text { Alpha }\end{array}$ \\
\hline \multirow{2}{*}{$\begin{array}{c}\text { Expatriate's } \\
\text { Social Capital }\end{array}$} & $\begin{array}{l}\text { Leader } \\
\text { Member } \\
\text { Exchange }\end{array}$ & $0.623 \sim 0.853$ & 3.632 & 60.528 & $0.550 \sim 0.732$ & 0.866 \\
\cline { 2 - 7 } & $\begin{array}{l}\text { Perceived } \\
\text { Organizational } \\
\text { Support }\end{array}$ & $0.715 \sim 0.896$ & 7.556 & 68.687 & $0.658 \sim 0.868$ & 0.954 \\
\hline \multirow{2}{*}{$\begin{array}{c}\text { Expatriate's } \\
\text { Cross-Cultural } \\
\text { Adjustments }\end{array}$} & & $0.844 \sim 0.924$ & 6.317 & 78.956 & $0.797 \sim 0.900$ & 0.926 \\
\hline \multirow{2}{*}{$\begin{array}{c}\text { Work-Role } \\
\text { Demand }\end{array}$} & Role novelty & $0.626 \sim 0.836$ & 3.928 & 56.120 & $0.516 \sim 0.747$ & 0.868 \\
\cline { 2 - 8 } & Role ambiguity & $0.606 \sim 0.837$ & 5.394 & 53.940 & $0.529 \sim 0.777$ & 0.904 \\
\cline { 2 - 7 } & Role conflict & $0.684 \sim 0.798$ & 5.392 & 53.919 & $0.607 \sim 0.739$ & 0.904 \\
\hline \multirow{2}{*}{$\begin{array}{c}\text { Roverload } \\
\text { Work-Family }\end{array}$} & $\begin{array}{l}\text { Work to family } \\
\text { conflict }\end{array}$ & $0.632 \sim 0.794$ & 1.644 & 54.790 & $0.658 \sim 0.712$ & 0.814 \\
\cline { 2 - 7 } & $\begin{array}{l}\text { Family to work } \\
\text { conflict }\end{array}$ & $0.805 \sim 0.845$ & 3.382 & 67.634 & $0.700 \sim 0.727$ & 0.890 \\
\hline
\end{tabular}

Source: Data Processed by the Authors

\subsection{Evaluation of the Measurement Model}

The empirical results as shown in Table 2 indicated that the leader-member exchange has a positive influence on expatriate adjustment $(\beta=0.2831, \mathrm{t}=27.1665)$. Furthermore, perceived organizational support has positive influence on expatriate adjustment $(\beta=0.0486, t=3.1700)$, perceived host attitude toward expatriate $(\beta=0.1066, \mathrm{t}=$ 7.7216). To sum up, social capital has positive influence on cross cultural adjustment $(\beta=0.1839, \mathrm{t}=8.1479)$. Therefore, hypothesis $\mathrm{H}_{1 \mathrm{a}}$ and $\mathrm{H}_{1 \mathrm{~b}}$ were supported.

Table 2 Evaluation of The Structural Model and Hypothesis Testing

\begin{tabular}{|c|l|c|c|}
\hline Hyp. & \multicolumn{1}{|c|}{ Path } & $\begin{array}{c}\text { Standardized } \\
\text { Estimate }\end{array}$ & t-Value \\
\hline $\mathrm{H}_{1 \mathrm{a}}$ & Leader Member Exchange $\rightarrow$ Expatriate's Adjustment & 0.2831 & 27.1665 \\
\hline $\mathrm{H}_{1 \mathrm{~b}}$ & Perceived Organizational Support $\rightarrow$ Expatriate's Adjustment & 0.0486 & 3.1700 \\
\hline
\end{tabular}

Source: Data Processed by the Authors

\subsection{The Moderating Effect of Work-Role Demand}

To evaluate the moderating effect of work-role demand in the influence of expatriate's social capital on their crosscultural adjustment, this study applied the K-mean method to divide the respondents into four groups with different levels of cross-cultural adjustment and work-role demand:
(1) Low cross-cultural adjustment / High work-role demand, (2) Low cross-cultural adjustment / Low work-role demand, (3) High cross-cultural adjustment / Low workrole demand, and (4) High cross-cultural adjustment / High work-role demand. The results showed that when the workrole demand is high, the influence of social capital $(\mathrm{F}=$ $71,924, \mathrm{p}<0.000$ ) on cross-cultural adjustment is inhibited. Therefore, $\mathrm{H}_{2}$ was supported. 


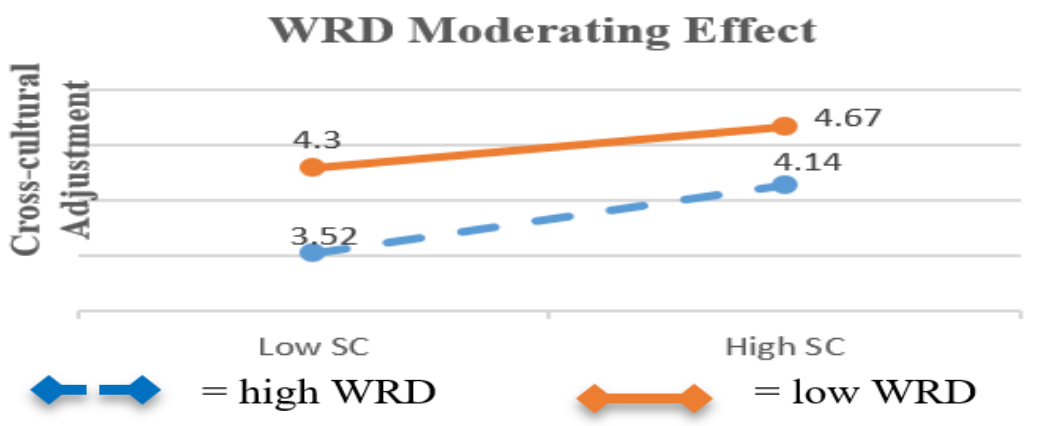

Figure 2 The Moderating Effect of Work-Role Demand

\subsection{The Moderating Effect of Work-Family Conflict}

To evaluate the moderating effect of work-family conflict in the influence of social capital on cross-cultural adjustment, this study applied the K-mean method to divide the respondents into four groups with different levels of cross-cultural adjustment and work-family conflict: (1)
Low cross-cultural adjustment / High work-family conflict, (2) Low cross-cultural adjustment / Low work-family conflict, (3) High cross-cultural adjustment / Low workfamily conflict, and (4) High cross-cultural adjustment / High work-family conflict. The results showed that when the work-family conflict is high, the influence of social capital on cross-cultural adjustment $(\mathrm{F}=70.518, \mathrm{p}<0.000)$ is inhibited. Therefore, $\mathrm{H}_{3}$ was supported.

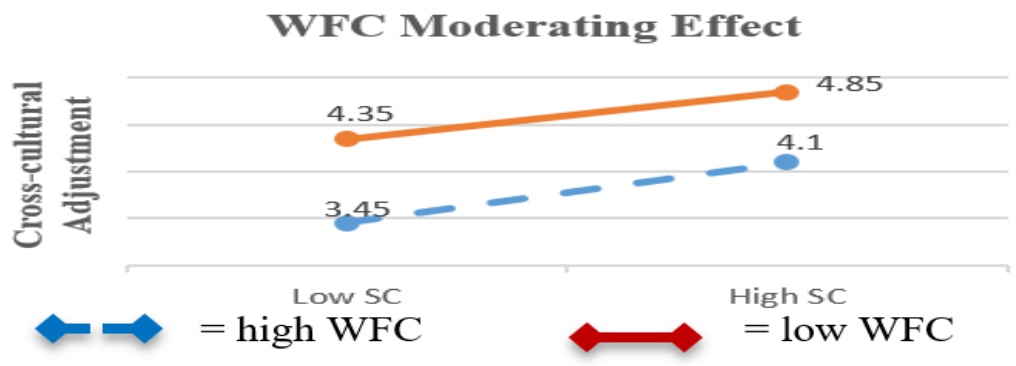

Figure 3 The Moderating Effect of Work-Family Conflict

\section{CONCLUSION}

The purpose of this research was to identify the influence of expatriate social capital on their cross-cultural adjustment. The moderating effects of work-role demand and workfamily conflict in the influence of expatriate's social capital on cross-cultural adjustment were also evaluated.

Expatriate's social capital has a significant impact on his / her cross-cultural adjustment, which further promote the expatriate's performance. This result is in line with those of previous studies. According to social exchange theory [2] and social capital theory [3], if the mutual relationship is satisfying, then the expatriate's performance in terms of adjustment will be improved. This study argued that perceived organizational support, and leader-member exchange become some of the important factors of social capital [4] [5] [47].

In an interactive expatriation environment, if the expatriates can develop and maintain the relationships with insiders and outsiders, they can blend into social capital that exist in their networks. It is argued that when the expatriates have higher social capital in form of higher leader-member exchange
(LMX), then the adjustment becomes easier [4]. Perceived organizational support (POS) is another important factor for expatriate's adjustment and performance. Organizational support theory [48] assumes that expatriates tend to develop global beliefs regarding the support from the organization, especially from the supervisor. It is suggested that when a supervisor value the expatriates' contributions and care about their existence, this kind of support will enable the expatriates to release their stress and to improve their adjustment to work. This study tried to extend POS into a broader perspective of social support which include the expatriate's perceived supports from organizations, coworkers, supervisors, friends, and families. [5] argued that these perceived social supports could be critical for expatriates.

Furthermore, two of the important moderators are presented in this study. Work-family conflict including the influence of parental demands, spouse and family member adaption should be taken into serious consideration. This study indicated that if work-family conflict is low and the support from family is high, this can facilitate better family adaptability, lower parental demand, and then the influence 
of expatriate's social capital on their cross-cultural adjustment will be amplified. Thus, the level of workfamily conflict has served as an inhibit factor to facilitate the expatriate's cross-cultural adjustment. This result is aligned with those from previous studies. [11] argued that work-family will negatively affect the expatriate's adjustment and performance. When an expatriate's family is in good condition, it is more likely that he / she can be well-adjusted to the foreign environment.

For the moderating role of work-role demand, this study results also indicated that higher level of work-role demand will inhibit expatriate's social capital and adjustment. This result is aligned with those from previous studies. Based on the role theory [46], role ambiguity (lack of clear information about the new role) will experience anxiety, distorted reality, increased dissatisfaction, which will further result in less effectiveness. [14] argued that the higher the role ambiguity, the less will be for the employees to predict the results of various behaviors and to use the past successful behavior to determine the ones. Therefore, role ambiguity may have a negative effect on the expatriate's effectiveness. Role conflict refers to a set of the roles that does not precisely fit, which may result in higher distress, less satisfaction, and lower performance [43]. Role conflict will result in lower adaptation and lower expatriation's effectiveness. Work overload will result in distress, which can finally result in responding inadequately and adjusting poorly. Therefore, role overload has a negative impact on the expatriate's adjustment and effectiveness. Thus, the effects of expatriate's social capital on his / her crosscultural adjustment will be moderated by the degree of work-load that the expatriate perceives. The higher the work-role demand (comprising role novelty, role ambiguity, role conflict, and role overload), the lower the relational skill that the expatriate has, as well as the lower the confidence to facilitate a better adjustment.

\section{REFERENCES}

[1] R.A. Guzzo, K.A. Noonan, E. Elron, Expatriate managers and the psychological contract. Journal of Applied Psychology. 79(4) (1994) 617-626.

[2] R. Takeuchi, M. Wang, S.V. Marinova, X. Yao, Role of domain-specific facets of perceived organizational support during expatriation and implications for performance. Organization Science. 20(3) (2009) 621634.

[3] P.S. Adler, S.W Kwon, Social capital: Prospects for a new concept. Academy of Management Review. 27(1) (2002) 17-40.

[4] M.L. Kraimer, S.J Wayne, R.A Jaworski, Sources of support and expatriate performance: The mediating role of expatriate adjustment. Personnel Psychology. 54(1) (2001) 71-99.
[5] B. Kupka, V. Cathro, Desperate housewives - social and professional isolation of German expatriated spouses. International Journal of Human Resources Management. 18(6) (2007) 951-968.

[6] R. Takeuchi, A critical review of expatriate adjustment research through a multiple stakeholder view: Progress, emerging trends, and prospects. Journal of Management. 36(4) (2010) 1040-1064.

[7] R. Takeuchi, S. Yun, P.E. Tesluk, An examination of crossover and spillover effects of spousal and expatriate cross-cultural adjustment on expatriate outcomes. Journal of Applied Psychology. 87 (2002) 655-666.

[8] P. Bhaskar-Shrinivas, D.A Harrison, M.A. Shaffer, D.M. Luk, Input-based and time-based models of international adjustment: Meta-analytic evidence and theoretical extensions. Academy of Management Journal. 48(2) (2005) 257-281.

[9] H.A Herleman, T.W Britt, P.Y Hashima, Ibasho and the adjustment, satisfaction, and well-being of expatriate spouses. International Journal of Intercultural Relations. 32(3) (2008) 282-299.

[10] M.F. Waxin, Expatriates' interaction adjustment: The direct and moderator effect of culture of origin. International Journal of Intercultural Relation. 28(1) (2004) 61-79.

[11] M.A. Shaffer, D.A. Harrison, K.M. Gilley, D.M Luk, Struggling for balance amid turbulence on international assignments: Work-family conflict, support and commitment. Journal of Management. 27(1) (2001) 99-121.

[12] A. Konanahalli, L.O Oyedele, J. Spillane, R. Coates, J.V Meding, J. Ebohon, Cross-cultural intelligence (CQ): It's impact on British expatriate adjustment on international construction projects. International Journal of Managing Projects in Business. 7(3) (2014) 423-448.

[13] J.S. Black, G.K. Stephens (1989), The influence of the spouse on American expatriate adjustment and intent to stay in Pacific Rim overseas assignments. Journal of Management. 15 (1989) 529-544.

[14]. Idris, M. K. (2011). Over time effects of role stress on psychological strain among Malaysian public university academics. International Journal of Business and Social Science. 2(9), 154-161.

[15] R.C Liden, R.T. Sparrowe, S.J Wayne, LeaderMember Exchange Theory: The Past and Potential for 
the Future. Research in Personnel and Human Resources Management. 15 (1997) 47-119.

[16] D.A Major, S.W. Kozlowski, G.T. Chao, P.D. Gardner. A longitudinal investigation of newcomer expectations, early socialization outcomes, and the moderating effects of role development factors. Journal of Applied Psychology. 80 (1995) 418-431.

[17] R. Dienesch, R. Liden, Leader-member exchange model of leadership: A critique and further development. Academy of Management Review. 11 (1986) 618-634.

[18] S.J. Wayne, L.M. Shore, W.H. Bommer, L.E Tetrick. (2002), The role of fair treatment and rewards in perceptions of organizational support and leadermember exchange. Journal of Applied Psychology. 87 (1995) 590-598.

[19] B. Kupka, V. Cathro, Desperate housewives - social and professional isolation of German expatriated spouses. International Journal of Human Resources Management. 18 (6) (2007) 951-968.

[20] M. Seeman, T.E Seeman, M. Sayles, Social networks and health status: A longitudinal analysis. Social Psychology Quarterly. 48 (1985) 237-248.

[21] R. Eisenberger, R. Huntington, S. Hutchison, D. Sowa. Perceived organizational support. Journal of Applied Psychology. 71 (1986) 500-507.

[22] L. Rhoades, R. Eisenberger, Perceived organizational support: A review of the literature. Journal of Applied Psychology. 87 (2002) 698-714.

[23] H. Levinson, H. (1965). Reciprocation: The relationship between man and organization. Administrative Science Quarterly. 9 (1965) 370-390.

[24] Z. Aycan, Acculturation of expatriate managers: A process model of adjustment and performance. In $\mathrm{Z}$. Aycan (Ed.), New approaches to employee management (Expatriate Management: Theory and Research), Greenwich, Connecticut: JAI Press. (1997) pp. 1-41.

[25] C.D Fisher, Social support and adjustment to work: A longitudinal study. Journal of Management. 11(3) (1985) 39-53.

[26] D.C. Ganster, M.R. Fusilier, M. R., \& Mayes, B. T. (1986). Role of social support in the experience of stress at work. Journal of Applied Psychology. 71(1) (1986) 102.
[27] R. Payne, (1980), Organizational stress and social support, Current concerns in occupational stress, pp. 269-298.

[28] J.S. Black, M. Mendenhall, G. Oddou, Toward a comprehensive model of international adjustment: An integration of multiple theoretical perspectives. Academy of Management Review. 16(2) (1991) 291-317.

[29] K. Oberg, Culture shock and the problem of adjustment in new cultural environments, Practical Anthropology. 7 (1960) 177-182.

[30] I. Torbiorn, Living Abroad. New York: Wiley. 1982

[31] P. Bhaskar-Shrinivas, D.A. Harrison, M. A., Shaffer, D.M Luk, (2005). Input-based and time-based models of international adjustment: Meta-analytic evidence and theoretical extensions. Academy of Management Journal. 48(2) (2005) 257-281.

[32] S.S. Ramalu, S. C. Rose, N. Kumar, J. Uli, Personality and expatriate performance: The mediating role of expatriate adjustment. The Journal of Applied Business Research. 26(6) (2010) 113-122.

[33] X. Zhou, J. Qin, A study on cross-cultural adjustment of Japanese and American expatriates in China. International Journal of Business and Management. 4(12) (2009)

[34] W.Y. Wu, M. Bodigeler-Koehler, The mediating effects of cross-cultural dynamic competencies on the relationship between multicultural personality and crosscultural adjustment. The International Journal of Human Resource Management. 24(21) (2003) 4026-4045.

[35] M.T. Ford, B.A Heinen, K.L. Langkamer, Work and family satisfaction and conflict: A meta-analysis of cross-domain relations. Journal of Applied Psychology. 92 (2007) 57-80.

[36] R.G Netemeyer, J.S. Boles, R. McMurrian, Development and validation of work-family and familywork conflict scales. Journal of Applied Psychology. 81 (1996) 400-410.

[37] J.R Edwards, N.P. Rothbard, Mechanisms linking work and family: Clarifying the relationship between work and family constructs. Academy of Management Review. 25(1) (2000) 178-199.

[38] J.H. Greenhaus, G.N. Powell. When work and family collide: Deciding between competing role demands. Organizational behavior and human decision processes, 90 (2) (2003) 291-303. 
[39] D.A. Harrison, M. A., Shaffer, P. BhaskarShrinivas, Going places: Roads more and less traveled in research on expatriate experiences. In Research in personnel and human resources management. Emerald Group Publishing Limited. 2004

[40] M.L Kraimer, S.J. Wayne, An examination of perceived organizational support as a multidimensional construct in the context of an expatriate assignment. Journal of Management. 30(2) (2004) 209237.

[41] J.R Rizzo, R.J. House, S.I. Lirtzman, Role conflict and ambiguity in complex organizations. Administrative Science Quarterly. 1970 150-163.

[42] C.B Handy, The age of paradox. Harvard Business Press. 1995.

[43] A. Cervoni, J. DeLucia-Waack, Role conflict and ambiguity as predictors of job satisfaction in high school counselors. Orchard Park High School, 2011 1-30

[44] J.S. Black, L.W. Porter, Managerial behaviors and job performance: A successful manager in Los Angeles may not succeed in Hong Kong. Journal of International Business Studies. 22(1) (1991) 99-113.

[45]. Statt, D. (1994), Psychology and the World of Work, Basingstoke: Macmillan.

[46] J. F. Hair, C.M. Ringle, M. Sarstedt, PLS-SEM: Indeed a silver bullet. Journal of Marketing theory and Practice. 19(2) (2011) 139-152.

[47] P.M. Podsakoff, S.B. MacKenzie, D.W Organ, Organizational citizenship behavior: Its nature, antecedents, and consequences. (2006)

[48] L. Rhoades, R. Eisenberger, S. Armeli. Affective commitment to the organization: The contribution of perceived organizational support. Journal of Applied Psychology. 86 (2001) 825-836. 